\author{
A. Marusenkov ${ }^{1}$, M. Leonov ${ }^{2, *}$, V. Korepanov ${ }^{1}, \mathrm{~S} . \operatorname{Leonov}^{1}$, \\ A. Koloskov ${ }^{2,3}$, Ye. Nakalov ${ }^{4}$, Yu. Otruba ${ }^{2}$ \\ ${ }^{1}$ Lviv Centre of Institute for Space Research, National Academy of Sciences of Ukraine \\ and State Space Agency of Ukraine (NASU and SSAU), 5a Naukova Str., Lviv, 79060, Ukraine \\ ${ }^{2}$ State Institution National Antarctic Scientific Center, Ministry of Education and Science of Ukraine, \\ 16 Taras Shevchenko Blvd., Kyiv, 01601, Ukraine \\ ${ }^{3}$ Institute of Radio Astronomy, National Academy of Sciences of Ukraine, \\ 4 Mystetstv St., Kharkiv, 61002, Ukraine \\ ${ }^{4}$ Carpathian Branch of S.I. Subbotin Institute of Geophysics, National Academy \\ of Sciences of Ukraine (CB IGPH of the NAS of Ukraine), 3-B Naukova Str., Lviv, 79060, Ukraine \\ * Corresponding author: g60s1981@gmail.com
}

\title{
UPGRADE OF THE ARGENTINE ISLANDS INTERMAGNET OBSERVATORY AT AKADEMIK VERNADSKY STATION, ANTARCTICA
}

\begin{abstract}
The article describes the main features of upgrading the magnetometric complex based on the LEMI-025 variometer in January-April 2019 at the geomagnetic observatory (code AIA) of the Ukrainian Antarctic Akademik Vernadsky station. The observatory's old magnetometric complex consisted of two LEMI-008 (No. 02 and No. 16) variometers and one POS-1 scalar magnetometer. The measurements of LEMI-008 and POS-1 were not mutually synchronized and this was one of the main problem. Every measuring instrument taken individually as a component of the whole magnetometric complex had good individual properties. However, in general, the complex as an entire system had reduced performance, mainly due to the lack of mutual synchronization of measurements. Some preliminary test results are also presented. Main objective. One of the main task of upgrading the AIA observatory was to install a new variometer that is compatible with the requirements of the 1-second INTERMAGNET data standard. For two decades, old LEMI-008 variometers at Akademik Vernadsky station have shown high baseline stability, which meets INTERMAGNET requirements. Unfortunately, the noise characteristics of old variometers, the accuracy of synchronization with UTC, and the resolution do not longer meet the current INTERMAGNET requirements for devices that produce 1-second data. Measurements of LEMI-008 variometers and POS-1 scalar magnetometer were not mutually synchronized. Due to lack of reliable mutual synchronization, the differences between the field vector modules, calculated indirectly from the variometer measurements and measured directly with the scalar magnetometer, varied and could be unreliable. With strong geomagnetic disturbances, this reduced the overall accuracy of the magnetometric complex as an integral measuring system, although the complex consisted of high-precision instruments. Only one of LEMI-008 variometers was equipped with GPS synchronization. This made data processing difficult. Therefore, one of the crucial upgrading tasks was creation of a system for mutual synchronization of measurements provided by the variometer LEMI-025 and the scalar magnetometer POS- 1 with an accuracy of approximately $0.1 \mathrm{~s}$ (but not worse than $1 \mathrm{~s}$ ) using control computer. Methods. The problem of mutual synchronization of the measurements of the LEMI025 variometer and the POS-1 scalar magnetometer (at the stage of upgrading the magnetometric complex as a whole system) was solved using a control computer by periodical adjusting the POS-1 clock and starting its measurement cycles with a given timing advance. New data arrays were obtained while the LEMI-025 magnetometer was operated in test mode. Using the Bartlett's method and spectral harmonics averaging, the noise level of the magnetometers during a geomagnetically quiet day
\end{abstract}

Cite: Marusenkov A., Leonov M., Korepanov V., Leonov S., Koloskov A., Nakalov Ye., Otruba Yu. Upgrade of the Argentine Islands INTERMAGNET observatory at Akademik Vernadsky station, Antarctica. Ukrainian Antarctic Journal, 2019. № 1(18), $103-115$. 
was estimated. The results of absolute measurements of the geomagnetic field components, regularly carried out in the observatory by two methods, were analyzed and the baselines values of the LEMI-025 magnetometer were estimated. The comparative analysis of the records of the Earth magnetic field intensity, obtained by direct measurements with a scalar magnetometer POS-1 and calculated from the baseline-adjusted components of the LEMI-025 variometer, was performed. Using the obtained baseline values and the total field difference signals the high calibration accuracy of the new variometer was confirmed and the orientation errors of its sensitivity axes in the geographical coordinate frame were estimated. Conclusions. Our preliminary results confirm that the characteristics of new LEMI-025 variometer meet the INTERMAGNET requirements. The orientation errors of LEMI- 025 sensor do not exceed 5 arc minutes. The base line is quite stable. All its components have dispersion within $\pm 2 \mathrm{nT}$, without pronounced temporal drift. The test results of LEMI-025 variometer showed that the characteristics of all magnetometric instruments in the measuring pavilion of the AIA observatory should be mutually agreed in terms of electromagnetic compatibility.

Keywords: 1-second INTERMAGNET magnetometer, LEMI-025 variometer, the technique of synchronous measurement, LEMI-025 variometer noise.

\section{INTRODUCTION}

Geomagnetic observatory Argentine Islands (IAGA code is AIA) was established in 1955 as one of the key research facilities at the British Antarctic station (Cotton and Simmons, 1986). Local K-indices derived at the observatory were used for calculation of the planetary $\mathrm{K}_{\mathrm{p}}$ index of geomagnetic activity (Cotton and Simmons, 1986).

Nowadays AIA is the only one INTERMAGNET observation point in the region of Antarctic Peninsula (the nearest Orcadas observatory is located more than $1000 \mathrm{~km}$ away). High-quality magnetic measurements at the AIA observatory are important for creating global geomagnetic field models. In addition, the surrounding of the Akademik Vernadsky station is characterized by very low level of anthropogenic electromagnetic pollution that makes it possible to carry out high quality magnetic measurements. The low level of artificial noise can be clearly illustrated by round-the-clock registration of up to seven Schumann resonance peaks by extreme low frequency (ELF) induction-coil magnetometer operating at the station since March 2002, (Koloskov, 2013).

Regular magnetic measurements have been carried out at the observatory since 1957 (Cotton and Simmons, 1986). Initially the pair of La Cour magnetographs, sensitive and coarse ones, was used to record the variations of the magnetic field. The following pure mechanical instruments were used to support the absolute measurements of the Earth magnetic field components (Cotton and Simmons, 1986): three

\section{4}

Quartz Horizontal Magnetometers measured the horizontal field component, two Zero Magnetic Balances recorded the vertical component, and a Kewpattern magnetometer was used to measure declination, an angle between the geographic and the geomagnetic meridians.

Precision measurements of the Earth's magnetic field with almost absolute accuracy were started in 1969, when proton magnetometer was installed. Since 1974, a three-component fluxgate magnetometer EDA was used to record field changes in analog form, and after 1980 measurements were carried out digitally using a new data logger (Cotton and Simmons, 1986).

In 1996, the United Kingdom transferred Faraday base (now Akademik Vernadsky station) to Ukraine. At that time such instruments were used for absolute measurements, namely: DI-flux non-magnetic theodolite THEO-020B with a Bartington MAG-01H fluxgate sensor mounted on its telescope (this device is still used) and the precession proton magnetometer GM-122. Two EDA three-component fluxgate magnetometers FM-100B and one La Cour magnetograph were used to record field variations (Bakhmutov, 1997).

In 1998-2003, AIA observatory was equipped with two new LEMI-008 variometers (one with serial number 02 , which is oriented in the geomagnetic coordinate system, and the other with number 16 , which is oriented in the geographic coordinate system). These devices were designed and manufactured in Ukraine (by Lviv Center of Space Research Institute) and had a low noise level and high temperature, ISSN 1727-7485. Ukrainian Antarctic Journal. 2019, № 1(18) 
stability. In 2004, the observatory was accepted into the INTERMAGNET network (Melnik, Bakhmutov, 2008). The PMP-8 proton magnetometer has been used for total field measurements since 2005. In 2011, POS-1 Overhauser magnetometer was installed as a scalar magnetometer for continuous recording of magnetic field strength.

Currently, LEMI-008\#16 is the main variometer of the Argentine Islands Observatory. Equipped with a sensor oriented according to the geographic coordinate system, this variometer is operated in conjunction with the POS-1 scalar magnetometer. However, lack of synchronization of the LEMI-008\#16 and POS-1 measurements during strong geomagnetic disturbances led to discrepancies between the field strengths measured by the scalar magnetometer and calculated from the variometer data.

During twenty years of operation, LEMI-008 variometers demonstrated high baseline stability; their noise characteristics, synchronization accuracy with UTC, coarse resolution $(0.1 \mathrm{nT})$ do not meet the requirements for modern 1-second instruments. Therefore, one of the primary tasks of the observatory upgrade was installation of a new variometer compatible with the INTERMAGNET requirements to 1-second data standard (Turbitt at al, 2013).

Currently, some weaknesses in old magnetometric instruments have become apparent. The operation of POS-1 proton magnetometer is controlled by its internal clock, which has time error relative to UTC (Coordinated Universal Time), which is necessary to correct manually from time to time. Asynchronous operation of the variometer and the proton magnetometer made it difficult to compare their records, which is one of the standard procedures for data verification at the geomagnetic observatories.

In addition, POS-1 sensor generates a periodic magnetic field interference that is recorded by the variometers. Therefore, the second important task was to provide the synchronous operation of POS-1 and the new variometer by supporting simultaneous linking to UTC timestamps. In our opinion, the synchronous operation of both devices can significantly improve POS-1 interference suppression during data post processing.

\section{MATERIALS AND METHODS}

\section{Description of the new system}

INTERMAGNET 1-second standard magnetometer LEMI-025 (Marusenkov, 2014) was chosen to be used in future as a main variometer for AIA observatory. This instrument has low noise level, good synchronization accuracy (Swan et al, 2016) and it is successfully exploited in many geomagnetic observatories over the Globe (Nahayo et al, 2019, Marusenkov, 2014), including Antarctic region (Rasson, 2014).

The data acquisition system was developed specifically for this project that met the following requirements for synchronization of LEMI-025 and POS-1 magnetometer:

1) Simplicity and reliability.

2) Accuracy of mutual synchronization of devices at the level of 0.1 seconds ( $0.5-1.0$ seconds max).

3) Independence on interruptions of GPS synchronization.

4) Periodicity of reading POS-1 data is $10 \mathrm{~s}$.

The proton magnetometer can operate in one of two modes: continuous measurements with a predetermined frequency of readings or in a single measurement mode, which is initiated by the corresponding command. In both modes, the start of the measurement cycle is synchronized to the POS- 1 internal clock, but starts occur at different times: at the top of the second $(* .00 \mathrm{~s})$ in continuous mode and in the middle of the second $(* .50 \mathrm{~s})$ for a single measurement. POS-1 and LEMI-025 responses to the same test harmonic wave with amplitude of $550 \mathrm{nT}$ and period of $100 \mathrm{~s}$ were analyzed. This test revealed that, even with accurate POS-1 clock UTC synchronization in the both modes of POS-1 operation the mutual synchronization of the devices cannot be achieved at the required level of $0.1 \mathrm{~s}$. In the continuous mode, the POS-1 samples were delayed relatively to the LEMI- 025 ones by $0.2 \mathrm{~s}$, in the single measurement mode, contrary, got ahead by $0.3 \mathrm{~s}$.

In order to meet the requirements to the devices synchronization the following timing diagram (Fig. 1) was proposed. POS-1 measurement cycle consists of three stages: polarization, precession and data processing (Sapunov et al., 2001; Khomutov et al., 2004). 


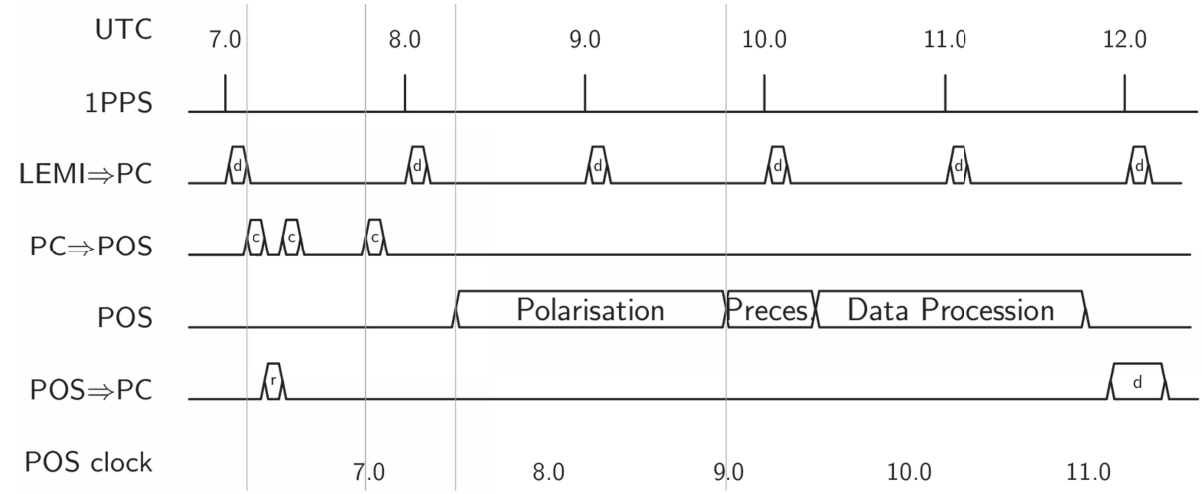

Fig. 1. Timing Diagram of POS-1 synchronization

In fact, data reading from the instrument means that the input signal is averaged during the precession interval. The time of the precession signal decay depends on the gradient of the measured field and approximately is equal to $0.7 \mathrm{~s}$ for the homogeneous field and 10-30 ms for the field gradient of 10000$20000 \mathrm{nT} / \mathrm{m}$ (POS-1 User manual, 2004).

The main idea is to start POS-1 cycle in such a moment, that the middle of the precession stage coincides with the top of the UTC-second: the 10th, 20th, 30th second and so on. In order to achieve this timing, each hour we adjust the POS-1 clock by introducing some lag in respect to the true time. A value of the lag has to be determined for a particular sensor and magnetic field homogeneity level. Currently we use the lag value $0.22 \mathrm{~s}$ that was found empirically for an instrument operated in a non-uniform field with a gradient around $1000 \mathrm{nT} / \mathrm{m}$. Other lag value might be determined and set using developed data acquisition software, if necessary.

POS- 1 clock correction is performed using LEMI025 variometer, which produces a data packet every second ( 153 bytes, 57600 baud). Start of the packet is shifted by $1.5 \mathrm{~ms}$ relative to the top of the second of the instrument internal clock, which in turn is GPSsynchronized with UTC. The data packet $\left(\mathrm{t}_{\mathrm{p}}=27 \mathrm{~ms}\right)$ is fed into the serial port of the computer. The program decodes the timestamp from the data packet and sends to POS-1 hourly commands to set the clock time and to run continuous measurements with the sampling interval of $10 \mathrm{~s}$. If there is no data for a certain period of time or POS-1 timestamps are in-

\section{6}

correct, the clock is automatically corrected and the magnetometer measurement cycle is restarted.

In addition to device synchronization, a specially designed application performs the following functions:

- control of LEMI-025 and POS-1 magnetometers;

- real-time data visualization: LEMI-025 magnetometer (three components of $\mathrm{B}_{\mathrm{X}}, \mathrm{B}_{\mathrm{Y}}, \mathrm{B}_{\mathrm{Z}}$ magnetic field, temperatures of sensor and electronics unit); POS-1 magnetometer readings; the difference between total magnetic field intensity values recorded by a scalar magnetometer POS-1 and computed from baselineadjusted variometer LEMI-025 component values;

- filtering and decimation of data according to the requirements of INTERMAGNET;

- writing data to text files;

- converting binary data files from LEMI-025 compact flash memory card into text files;

- visualization of accumulated data;

- editing the title of 1-second and 1-minute files in accordance with the requirements of IAGA-2002 format.

On the base of $10 \mathrm{~Hz}$ LEMI-025 data the program calculates 1-second data using 61-point digital Gaussian filter. The filtered values are centered to the top of the second. 1-second LEMI-025 data and 10-second POS-1 data are further filtered, using Gaussian filters with 91 and 11 coefficients respectively (St-Louis, 2012, Appendix E-1), and decimated to 1-minute values centered at the top of the minute.

The program runs on a devoted computer with the operating system Debian 9.6. The PC and operation system were configured to meet our requirements. The main features are as follows:

ISSN 1727-7485. Ukrainian Antarctic Journal. 2019, № 1(18) 
- Embedded hardware supported RS-232 serial ports (this is essential for minimization of synchronization delays);

- UTC synchronized system clock (this is very useful for testing purposes, but not necessary for instrument synchronization);

- SSH server for remote access to the system through the command line interface;

- FTP file server for remote access to recorded data files;

- VNC server for remote control of the instruments;

- Firewall configuration tool for system protection against network attacks;

- Automatic restart of the data acquisition program after the system reboot - the instruments data collecting is restored in unattended way;

- Control of Uninterruptible Power Supply (UPS) operation, safe shutdown and automatic system reboot during power mains unplanned outages.

Currently we used ordinal office desktop Dell Vostro 3670 with addition PCIe-RS232 card. The system could also be controlled by mini-PC, which usually have smaller power consumption and a weaker own magnetic moment.

\section{System deployment at the observatory}

Installation of the new data acquisition system on the base of LEMI-025 variometer and the existing POS-1 scalar magnetometer were carried out during the seasonal expedition to the Ukrainian Antarctic Akademik Vernadsky station in January-April 2019. The system operation was launched in a testing mode.

The old EDA variometer which is out of operation since 2006 as well as all the needless cables was removed from the variometer room. The short survey of the total magnetic field intensity distribution in the variometer room had been carried out, including estimation of the pillar difference between the POS-1 sensor pillar and the site intended for LEMI-025 sensor installation. The refined gradients between the DI-flux, PMP-8, POS-1, LEMI-008\#16, LEMI$025 \# 63$ pillars are shown in the variation pavilion plan (Fig. 2).
From February 27, 2019, the LEMI-025 magnetometer was installed at the intended regular position in the variation pavilion (Fig. 2). The probe was leveled and oriented along geomagnetic meridian (HDZ orientation). The magnetometer GPS antenna was installed in the testing room. It was found that the LEMI-025 GPS receiver confidently receives signals from at least four satellites and uninterruptedly provides timestamp information. However, it is worth noting that the tourist navigator GARMIN GPSmap60 showed a level of uncertain reception (only $1-2$ satellites). This demonstrates the benefits of more sensitive GPS unit used in the LEMI-025, which makes it unnecessary to deploy the antenna outdoors.

After mounting the new LEMI-025 magnetometer, a repeat survey of the total field distribution in the variometer room had been performed and no significant changes were detected in comparison with the results of the first survey. The total field strength in the room is from 4 to $28 \mathrm{nT}$ less than that of the POS-1 pillar. The results of the total field distribution surveys have demonstrated that the LEMI-025 sensor was placed in a homogeneous area.

The dedicated computer of the new data acquisition system was installed in the fiberglass pavilion, at a distance of about $60 \mathrm{~m}$ from the Variometer Hut. The PC was connected to the station's LAN via Wi-Fi. Access to the computer via SSH and FTP had been tested and confirmed. The firewall was successfully configured and VNC operation was further used for remote control and monitoring of the data acquisition process.

During February-March 2019, a series of absolute measurements (59 sessions) were conducted and the average values of the magnetic field components were calculated. Using these values, on March 10, 2019, the sensor of LEMI-025 magnetometer was oriented toward the geographical meridian (XYZ orientation).

After a period of temperature stabilization, the first LEMI-025 magnetometer records were analyzed and a pulsation with a period of 10 seconds and amplitude of up to $40 \mathrm{pT}$ was detected in the Z-channel data. Minor 10 second ripples were also present in $\mathrm{X}-$, Y-channels. As expected, the POS-1 magnetometer was found to be the source of the interference. POS-1 probe and control unit are located in the sca- 
lar measuring room (Fig. 2) at a distance of 4.7 meters from LEMI-025 sensor.

It was found that occasionally (approximately once a week) the total field difference signal quickly changes the level by $0.1-0.7 \mathrm{nT}$ (see bottom plot $\Delta \mathrm{F}$ in Fig. 5). More detailed analysis of magnetometer data showed that these "jumps" were also visible in the records of all three variometers LEMI-008\#02, \#16, LEMI-025\#63, and they were more pronounced in the records of LEMI-008\#02. The nature of those "jumps" was revealed later: they were caused by a magnetization change of three power supplies located in the test room (Fig. 2) during $220 \mathrm{~V} \mathrm{AC} \mathrm{power} \mathrm{failure/recovery.}$

During April 6-7, the temperature in the variometer room had changed intentionally by $3-4{ }^{\circ} \mathrm{C}$ for a few hours and then returned to a previous value. In the result the total field difference at this time changed by $1.5 \mathrm{nT}$ and then returned to previous value. Further studies have to be made to evaluate the temperature dependences of every individual component of LEMI-025 magnetometer.

It was also found that sometimes, when LEMI025 magnetometer is turned on or restarted, incorrect calibration coefficients may be set, which leads to improper magnetometer records. The instrument has to be restarted and the correct calibration coefficient values have to be loaded manually using the data acquisition program to resolve this issue. So, the observatory personnel have to check carefully each case of LEMI-025 restarting until the manufacturer fixes this problem.

\section{RESULTS}

\section{Total field differences analysis}

Comparison of the total field intensity values recorded by a scalar magnetometer and computed from baseline-adjusted variometer component values is one of the quality control methods used in the observatory practice (St-Louis, 2012, subsection 6.5). Usually the variometer total field Fv is computed using baseline-adjusted records; however, LEMI-025 bias signals are known with high accuracy after proper calibration. So, instead of baseline-values Bcx, Bcy, Bcz derived from the absolute

\section{8}

measurements we used those from LEMI-025 bias signals:

$$
\begin{gathered}
\mathrm{Bcx}=-\mathrm{Nx} \times \mathrm{Kx} ; \mathrm{Bcy}=-\mathrm{Ny} \times \mathrm{Ky} ; \\
\mathrm{Bcz}=-\mathrm{Nz} \times \mathrm{Kz},
\end{gathered}
$$

where Nx, Ny, Nz are LEMI-025 compensator digital-to-analogue converter codes, $\mathrm{Nx}=8900$ bit, $\mathrm{Ny}=2514$ bit, $\mathrm{Nz}=-14370$ bit; Kx, Ky, Kz LEMI-025 bias signals' calibration coefficients, $\mathrm{Kx}=$ $=-2.222207 \mathrm{nT} / \mathrm{bit}, \mathrm{Ky}=-2.216161 \mathrm{nT} / \mathrm{bit}, \mathrm{Kz}=$ $=-2.215711 \mathrm{nT} / \mathrm{bit}$.

As LEMI-025 sensor was oriented along geographic meridian, the total field difference $\Delta \mathrm{F}$ values were computed by the following formula:

$$
\begin{gathered}
\Delta \mathrm{F}=\left[(\mathrm{Bcx}+\mathrm{Bx})^{2}+(\mathrm{Bcy}+\mathrm{By})^{2}\right. \\
\left.+(\mathrm{Bcz}+\mathrm{Bz})^{2}\right]^{1 / 2}-\mathrm{Fs}+\Delta \mathrm{F}_{\text {pier }},
\end{gathered}
$$

where $\mathrm{Bx}, \mathrm{By}, \mathrm{Bz}$ are LEMI-025 variation values; Fs the total field value from POS $-1 ; \Delta \mathrm{F}_{\text {pier }}$ - the total field pier difference between the total field values at POS-1 sensor and LEMI-025 sensor locations, $\Delta \mathrm{F}_{\text {pier }}=17.5 \mathrm{nT}$.

In order to better determine the residuals of the geomagnetic filed variations in $\Delta \mathrm{F}$ time series, the time interval of 5 days with one the most disturbed day in May, 2019 was selected. Local K-indices obtained during data processing at the Akademik Vernadsky station were within $1-5$ for the disturbed day, May, 14th, and within 0-3 for the other days of the selected time interval.

The data acquired with $10 \mathrm{~s}$ sampling interval were compared: Fs (POS-1) and Fv (LEMI-025) wave forms and their difference $\Delta \mathrm{F}$ are given on the left upper and bottom panels in Fig. 3. We can see that during magnetic storm the total field strength deviated as much as $150 \mathrm{nT}$. The associated total field difference deviations do not exceed $0.1 \mathrm{nT}$. This means that the instruments' scale factors are matched quite well, and their mutual synchronization are good. The disturbance $(0.2 \mathrm{nT})$ in $\Delta \mathrm{F}$ signal at $19^{\text {th }}$ hour of the analyzed time interval coincides with carrying out of the absolute measurements.

Spectra of analyzed signals are given in the right panel in Fig. 3. Spectrum $\mathrm{S}(\mathrm{Fv})$ of the total magnetic field variations computed from LEMI-025 data was calculated for records with the sampling period $1 \mathrm{~s}$. A ISSN 1727-7485. Ukrainian Antarctic Journal. 2019, № 1(18) 


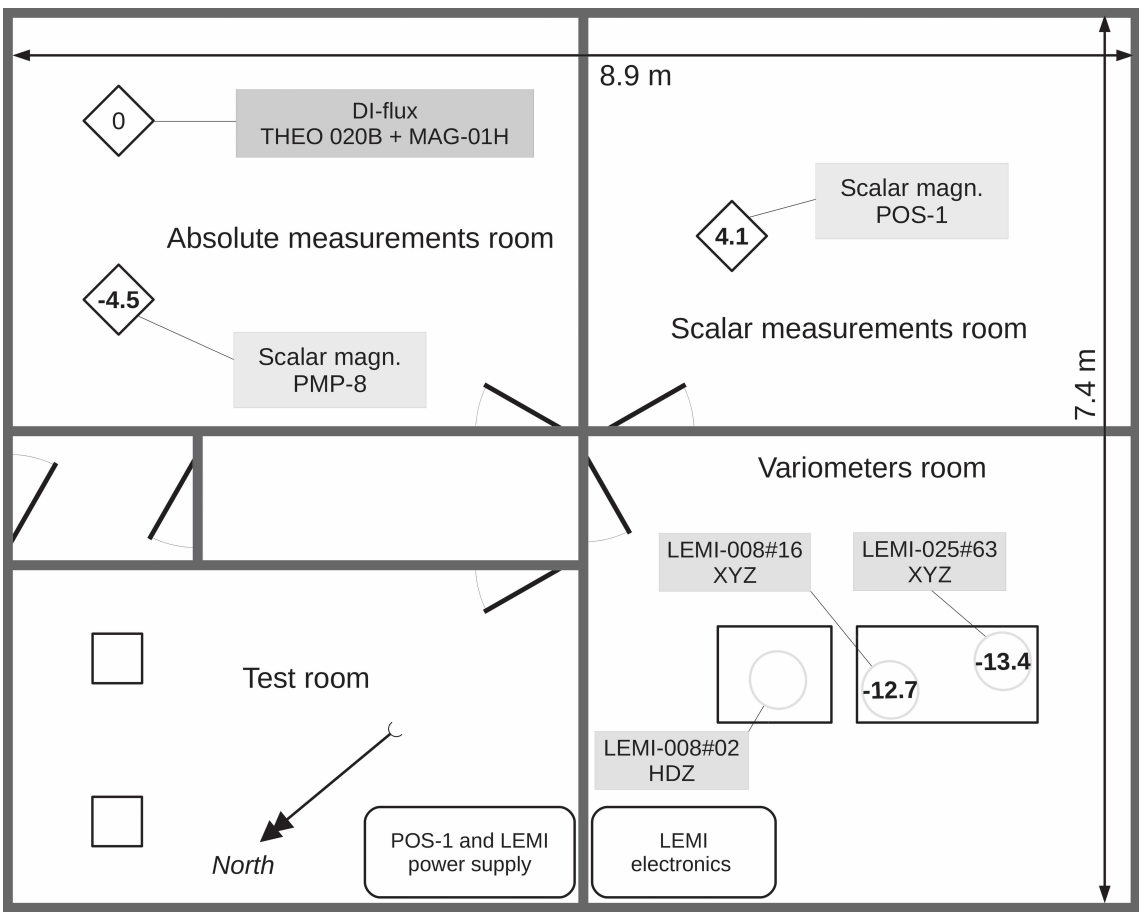

Fig. 2. Floor plan of the Variometer Hut

similar spectrum for the signals measured by POS-1 was computed for records with the sampling period $10 \mathrm{~s}$, and so was spectrum $\mathrm{S}(\Delta \mathrm{F})$ of the difference signal of the total magnetic field. The origin of the upper part $(>0.1 \mathrm{~Hz})$ of $\mathrm{S}(\mathrm{Fv})$ is own noise of LEMI025. It was estimated within the laboratory magnetic shield and its spectrum is shown in the figure as the gray dashed line. Natural geomagnetic variations are mainly contributed to $\mathrm{S}(\mathrm{Fv})$ at the lower frequencies $(<0.1 \mathrm{~Hz})$. Comparing $\mathrm{S}(\mathrm{Fv}), \mathrm{S}(\mathrm{Fs})$ and $\mathrm{S}(\Delta \mathrm{F})$ we can conclude that the total field difference spectrum is basically defined by POS-1 own noises. It should be noted that POS-1 provides for each reading the so called Quality Measurement Criterion (QMC), which closely correlates with instrument noises (Denisov et al, 2006). Denisov et al (2006) reported some typical QMC values for POS-1 magnetometers in the range of 8-12 pT. POS-1 instrument, installed at the AIA Observatory, has much higher QMC values, which are approximately $30-40 \mathrm{pT}$. The elevation of $\mathrm{S}(\Delta \mathrm{F})$ level in the frequency band $0.2-1 \mathrm{mHz}$ probably originates from the LEMI-025 temperature dependence. At least, the frequency band of these spectrum irregularities is in good agreement with periods of cyclic operation of heating elements, which lay in the range 1000-4000 s. At the most lower frequencies of about $0.1 \mathrm{mHz}$ the contributions in $\mathrm{S}(\Delta \mathrm{F})$ from POS-1 and LEMI-025 own noises are approximately equal to each other.

\section{Noise level estimations}

For noise estimations the records during April, $26^{\text {th }}$ (one of the quietest days with provisional local Kindex $\leq 2$ ) were selected.

Prior to the noise spectra calculations, the periodic 10-second signals' artefacts induced by POS-1 operation were semi-automatically removed from the records LEMI-025\#63 and LEMI-008\#16 magnetometers.

In order to produce power spectral density (PSD) we exploited the Bartlett's method (Bartlett, 1950) with a 8192-point fast Fourier transform (FFT). The linear trend was removing at each 8192-point segment of 1-second data and a Hann window function, giving power spectral density estimation down to approximately $0.1 \mathrm{mHz}$. PSD was computed using a 

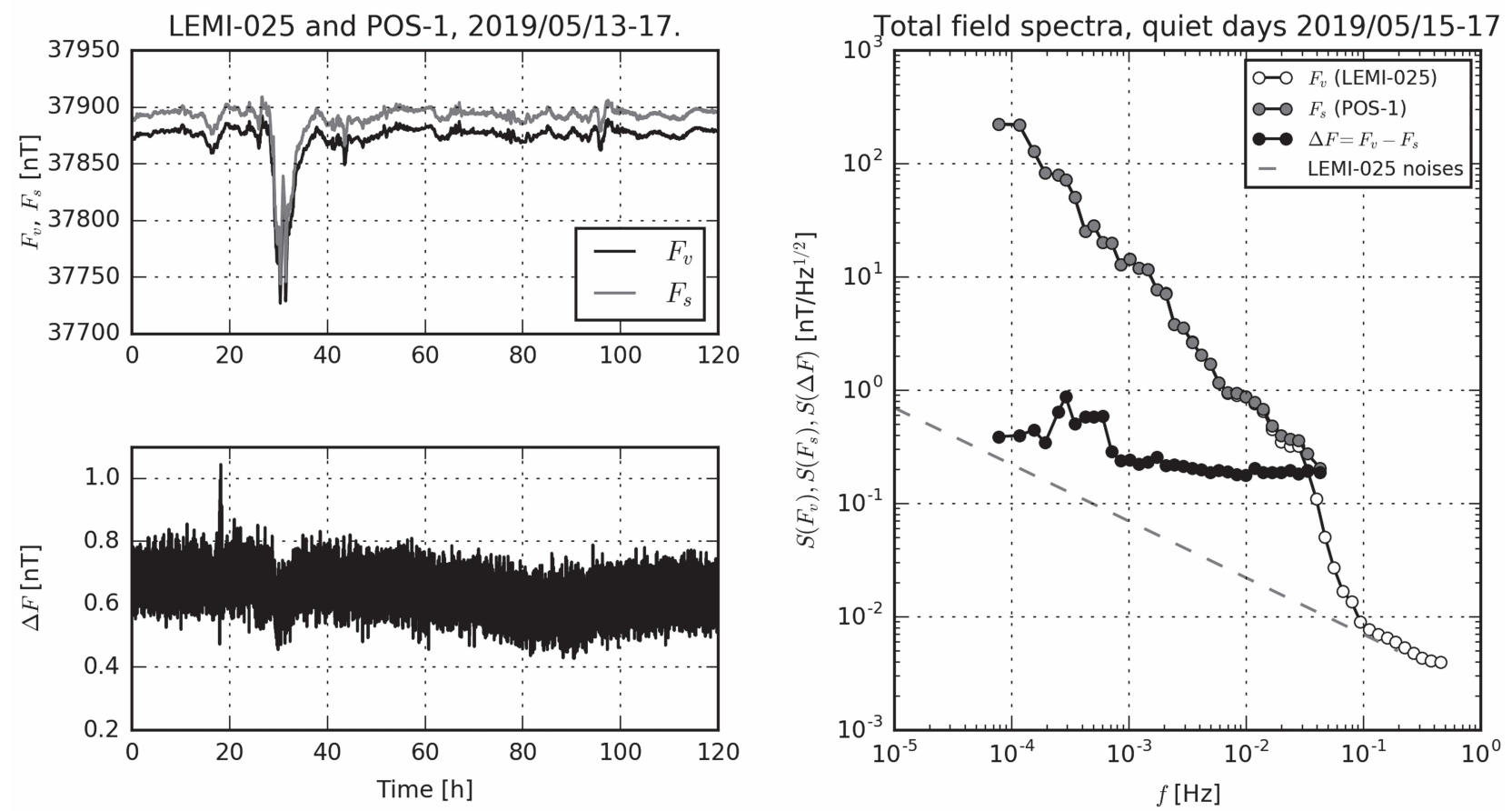

Fig. 3. Total field and its difference measured by POS-1 and calculated using LEMI-025 components: wave forms and spectra

Python-based SciPy library function "welch" from the Signal Processing toolbox (Burovski et al, 2017, p. 1119-1121). These spectra were further averaged to the samples evenly distributed on the logarithmic frequency scale.

Along with LEMI-025\#63 the records of other two instruments were analyzed: LEMI-008\#16 currently a primary variometer of Argentine Islands observatory and the provisional variometer data from the US INTERMAGNET observatory Fredericksburg. The estimates of the noise spectra for the frequency band $0.05-0.5 \mathrm{~Hz}$ are shown in Fig. 4. The natural geomagnetic variations are quite weak in this frequency band, so we can effectively compare instruments' noise level. Among three instruments LEMI025\#63 demonstrates the lowest noises asymptotically reaching $10 \mathrm{pT}$ quantization noise floor. LEMI008\#16 has the highest noises due to: a) coarse resolution of its data, $100 \mathrm{pT}$, and associated quantization noises; b) remains of the 10 -second interference, especially in X component. Fredericksburg variometer noises are slightly better than that of LEMI-008\#16, with exception of Y component, which power spect-

\section{0}

ral density is higher at lower frequencies. Thus, the use of LEMI-025\#63, with 4-5 times lower noise level, benefits in sufficient improving quality of the data, acquired at the Argentine Islands observatory.

\section{Baseline values analysis}

The absolute measurements at the Argentine Islands observatory were conducted four times per week on average by means of proton precession magnetometer and the DI-flux magnetometer using two similar approaches (Jankowsky and Sucksdorff, 1996, Hrvoic and Newitt, 2011, Worthington. and Matzka, 2017): the null method (Method A) and the residual or closeto-zero method (Method B). At the null method the position of the telescope is adjusted to give a zero magnetometer output. At the residual method the telescope is set to some convenient value (let say whole tens of minutes of arc) near the null position and the magnetometer reading is used to compute small angle correction to this convenient value.

Basing on the absolute measurement results the baseline values of the variometer LEMI-025 were ISSN 1727-7485. Ukrainian Antarctic Journal. 2019, № 1(18) 
Fredericksburg and Argentine Islands 1-sec data, Spectra, 2019-APR-26, $0 \leq \mathrm{K} \leq 2$
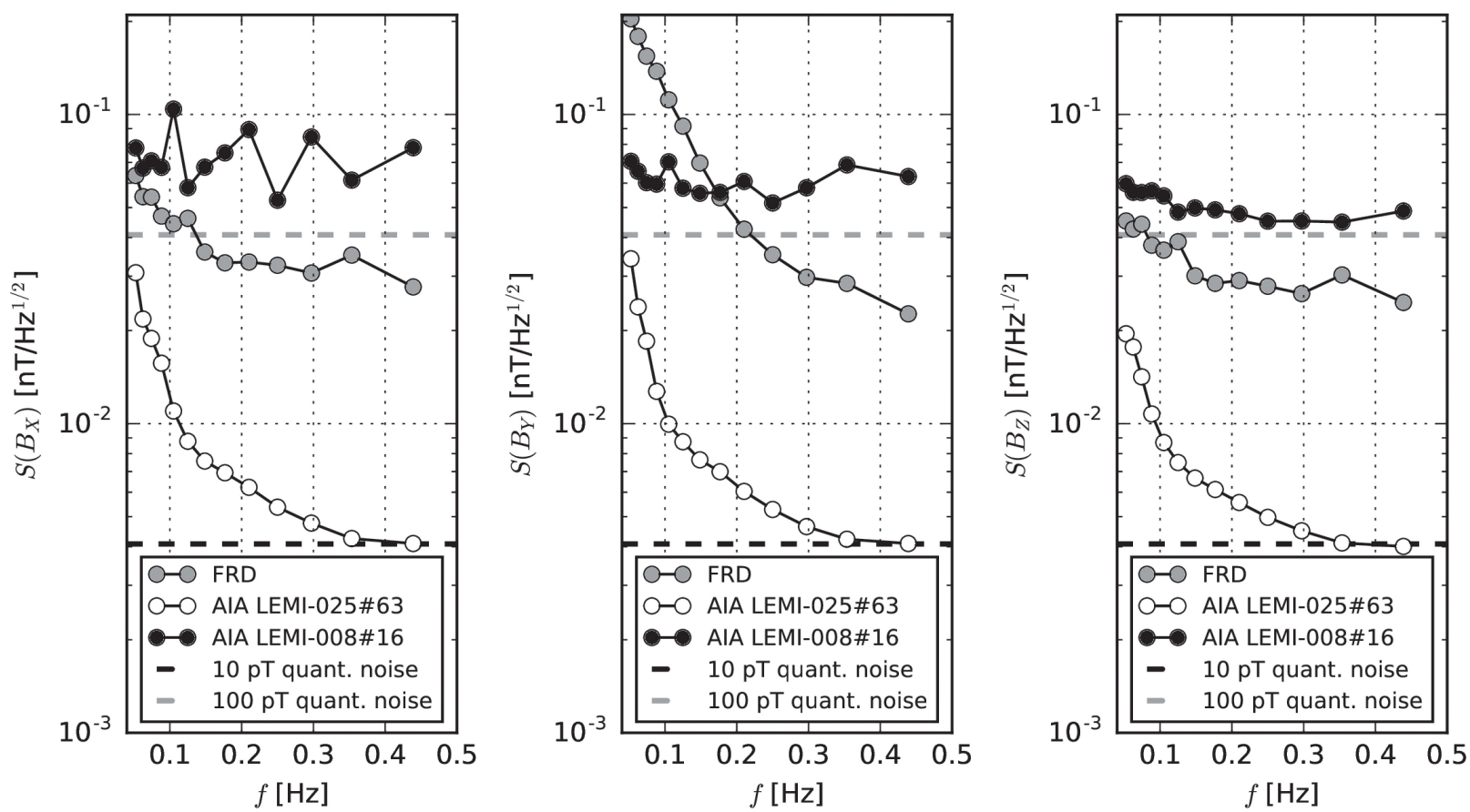

Fig. 4. Noise levels of LEMI-025\#63, LEMI-008\#16 at Argentine Islands and the variometer at Fredericksburg observatories

LEMI-025 N63 at AIA. Baseline values, PMP-8 +4.5 nT, April 2019.
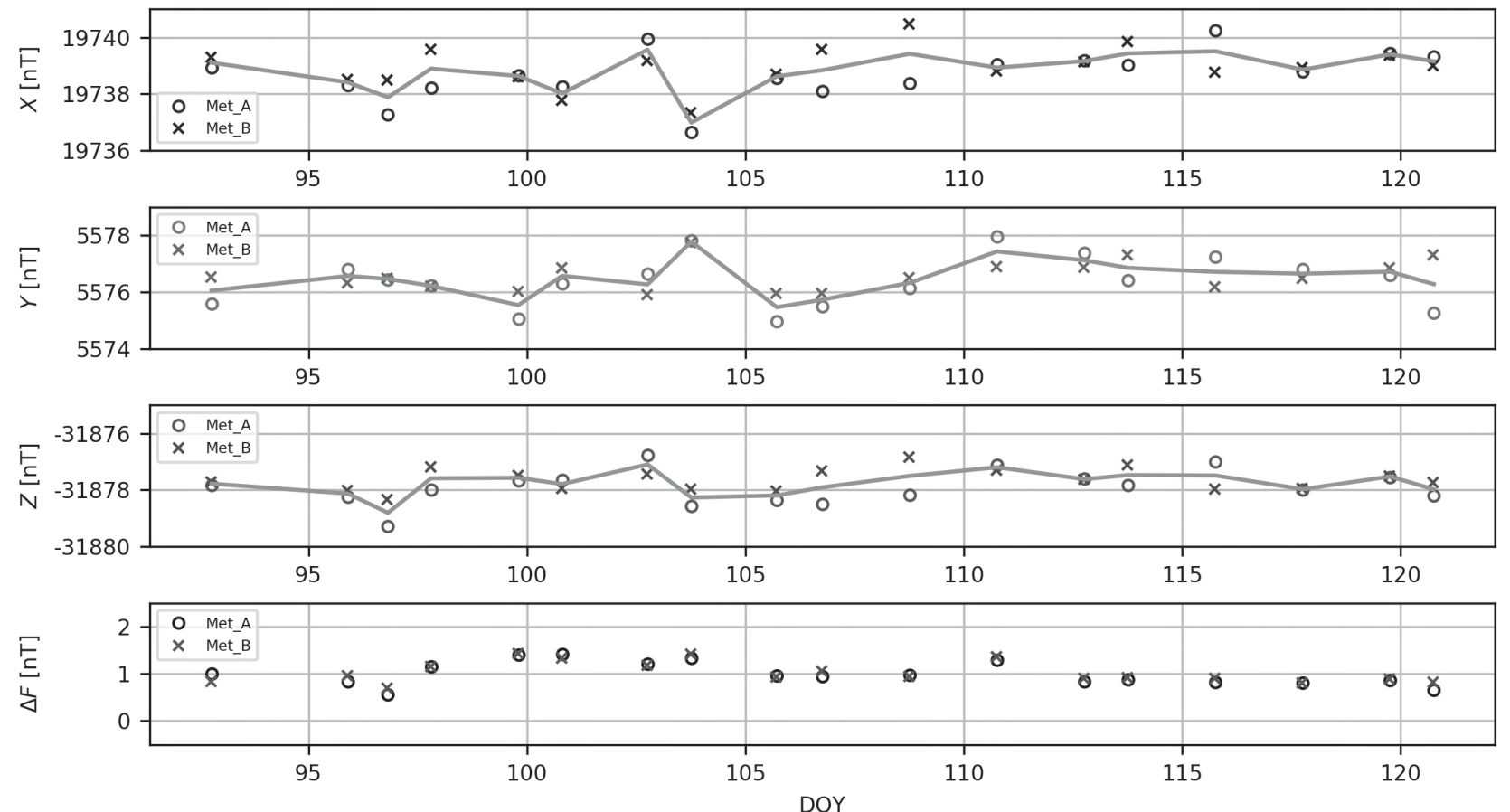

Fig. 5. LEMI-025 baseline values, April 2019 
computed for April 2019 (Fig. 5). The both methods' average values are marked by the gray lines. All components are stable enough (within $\pm 2 \mathrm{nT}$ ) - there is no pronounced time drift. The deviation of $\Delta \mathrm{F}$ is mainly caused by the power supply magnetic interferences during $220 \mathrm{~V}$ means outage.

\section{Sensor calibration and orientation accuracy}

In the previous subsections we showed that the total field computed basing on LEMI-025 bias signals and variations is very close to the values measured by POS-1 scalar magnetometer. The total field difference $\Delta \mathrm{F}$ does not exceed $1.5 \mathrm{nT}$, what is only $0.004 \%$ of the total field strength $\mathrm{F}=37900 \mathrm{nT}$. Taking into

Table. Declination, Inclination baseline values, April, 2019

\begin{tabular}{|c|c|c|c|c|}
\hline \multirow{2}{*}{ DOY } & \multicolumn{2}{|c|}{$\begin{array}{c}\text { Declination } \\
\text { baseline values }\end{array}$} & \multicolumn{2}{|c|}{$\begin{array}{c}\text { Inclination } \\
\text { baseline values }\end{array}$} \\
\hline & Method A & Method B & Method A & Method B \\
\hline 92 & $2.426^{\prime}$ & $2.561^{\prime}$ & $-4.629^{\prime}$ & $-4.576^{\prime}$ \\
\hline 95 & $2.649^{\prime}$ & $2.563^{\prime}$ & $-4.669^{\prime}$ & $-4.652^{\prime}$ \\
\hline 96 & $2.641^{\prime}$ & $2.591^{\prime}$ & $-4.803^{\prime}$ & $-4.665^{\prime}$ \\
\hline 97 & $2.562^{\prime}$ & $2.496^{\prime}$ & $-4.674^{\prime}$ & $-4.535^{\prime}$ \\
\hline 99 & $2.349^{\prime}$ & $2.509^{\prime}$ & $-4.648^{\prime}$ & $-4.624^{\prime}$ \\
\hline 100 & $2.572^{\prime}$ & $2.681^{\prime}$ & $-4.653^{\prime}$ & $-4.691^{\prime}$ \\
\hline 102 & $2.549^{\prime}$ & $2.466^{\prime}$ & $-4.481^{\prime}$ & $-4.585^{\prime}$ \\
\hline 103 & $2.888^{\prime}$ & $2.847^{\prime}$ & $-4.786^{\prime}$ & $-4.708^{\prime}$ \\
\hline 105 & $2.339^{\prime}$ & $2.493^{\prime}$ & $-4.697^{\prime}$ & $-4.649^{\prime}$ \\
\hline 106 & $2.446^{\prime}$ & $2.455^{\prime}$ & $-4.723^{\prime}$ & $-4.548^{\prime}$ \\
\hline 108 & $2.536^{\prime}$ & $2.499^{\prime}$ & $-4.675^{\prime}$ & $-4.447^{\prime}$ \\
\hline 110 & $2.800^{\prime}$ & $2.640^{\prime}$ & $-4.534^{\prime}$ & $-4.583^{\prime}$ \\
\hline 112 & $2.698^{\prime}$ & $2.620^{\prime}$ & $-4.561^{\prime}$ & $-4.577^{\prime}$ \\
\hline 113 & $2.551^{\prime}$ & $2.658^{\prime}$ & $-4.604^{\prime}$ & $-4.489^{\prime}$ \\
\hline 115 & $2.629^{\prime}$ & $2.528^{\prime}$ & $-4.456^{\prime}$ & $-4.635^{\prime}$ \\
\hline 117 & $2.626^{\prime}$ & $2.567^{\prime}$ & $-4.621^{\prime}$ & $-4.615^{\prime}$ \\
\hline 119 & $2.563^{\prime}$ & $2.606^{\prime}$ & $-4.557^{\prime}$ & $-4.554^{\prime}$ \\
\hline 120 & $2.352^{\prime}$ & $2.698^{\prime}$ & $-4.625^{\prime}$ & $-4.584^{\prime}$ \\
\hline Mean & $2.565^{\prime}$ & $2.582^{\prime}$ & $-4.633^{\prime}$ & $-4.595^{\prime}$ \\
\hline Total mean & \multicolumn{2}{|c|}{$2.574^{\prime}$} & \multicolumn{2}{|c|}{$-4.614^{\prime}$} \\
\hline Angular err. & \multicolumn{2}{|c|}{$0.749 \mathrm{mrad}$} & \multicolumn{2}{|c|}{$-1.342 \mathrm{mrad}$} \\
\hline Intermagnet & \multicolumn{4}{|c|}{$2 \mathrm{mrad}$} \\
\hline
\end{tabular}

\section{2}

account that the errors in component values $(\Delta \mathrm{Bx}$, $\Delta \mathrm{By}, \Delta \mathrm{Bz})$ contribute to the total field difference $\Delta \mathrm{F}$ as follows (St-Louis, 2012, p. 26):

$$
\Delta \mathrm{F}=\Delta \mathrm{Bx} \mathrm{Bx} / \mathrm{F}+\Delta \mathrm{By} \mathrm{By} / \mathrm{F}+\Delta \mathrm{Bz} \mathrm{Bz} / \mathrm{F}
$$

from the fact of small $\Delta \mathrm{F}$ we can conclude that scale factors and orthogonality of the magnetometer, at least channels $X$ and $Z$, are calibrated very well. Small $\Delta F$ values do not mean a small $\Delta \mathrm{By}$, because in our case it is summed with $15 \%$ weight. However, we can expect good calibration of Y channel as well, because the same calibration procedure was applied for all channels.

In order to check sensor orientation accuracy, we estimated declination and inclination of the Earth magnetic field vector in the reference frame of LEMI-025 sensor and compare it with the results of the absolute measurements. The obtained differences computed for April, 2019 - baseline values for declination and inclination - are given in Table. The comparisons with both methods of the absolute measurements yield similar results, which are very close to zero. During installation the sensor was leveled using a circular vial on the top of its rotating part of the platform. At the magnetometer calibration stage the both vertical axes - the circular vial and the magnetometer sensor - were adjusted with the rotating axis of the platform with accuracy better than 5 arc minutes. All these facts confirm that the sensor orientation meet INTERMAGNET requirements (Turbitt et al, 2013).

\section{CONCLUSIONS}

In order to meet the modern technical requirements of the INTERMAGNET network, LEMI-025 variometer has been installed at AIA geomagnetic observatory. The software-hardware complex for mutual synchronous registration of the geomagnetic field using LEMI-025 variometer and POS-1 scalar magnetometer has been developed. The new equipment works in test mode.

Our preliminary results showed that LEMI-025 characteristics meet INTERMAGNET requirements to 1 -second data. The orientation of LEMI-025 magnetometer sensor has been tuned with an accuracy of better than 5 arc minutes. The analysis of the com- 
plex performance during the first months confirms its stated characteristics: stability of basic values, synchronicity of data readout from both devices, low level of own noise of LEMI-025 variometer and accuracy of calibration. The baseline values of the variometer LEMI-025 shows, that all field components are stable enough (within $\pm 2 \mathrm{nT}$ ) and there is no pronounced time drift. The analysis of test data from the variometers of the Argentine Islands observatory, as well as of preliminary data from variometer of the Fredericksburg USA INTERMAGNET observatory testifies that LEMI-025\#63 shows the lowest noise level among the compared instruments. Thus, the use of LEMI-025\#63 improves the noise of instruments of the Argentine Islands Observatory by at least 4-5 times.

At the same time, several factors were identified, overcoming the influence of which will improve the quality of measurements. To reduce the level of interference, it is necessary to bring POS-1 scalar magnetometer sensor outside the variometric pavilion; this is one of the most important tasks for the near future. In addition, it is necessary to solve the problem of magnetic field interference caused by uninterruptible power supplies of the magnetometers.

The temperature dependence of LEMI-025\#63 requires more careful analysis and additional experiments. It may be necessary to provide better thermal stabilization of the sensor and/or electronics unit of LEMI-025 variometer by placing them in a thermal container, or to monitor temperature changes and make adjustments to measurements.

The noise of POS-1 scalar magnetometer is quite high and exceeds typical values for this type of device. Considering this fact and taking into account that POS-1 magnetometer sensor completed the manufacturer's declared life of 10 years, it should be replaced in the near future.

LEMI-008\#16 variometer has been operating at Akademik Vernadsky station since 2003. Thus, the completion of the test operation LEMI-025 and its transfer to normal operation is an urgent task. This will significantly improve productivity and increase the reliability and quality of geomagnetic data registration in AIA observatory.

\section{REFERENCES}

1. Bakhmutov, V.G. 1997. "Argentine Islands" Magnetic Observatory. "Akademik Vernadsky" station. Bulletin of Ukrainian Antarctic Centre, 1, 20-26.

2. Bartlett, M.S. 1950. Periodogram Analysis and Continuous Spectra. Biometrika, 37, 1-16.

3. Cotton, P. D., and Simmons, D. A. 1986. The geomagnetic observatory at Faraday, Argentine Islands. Polar Record, 23, 143, 192-195.

4. Denisov, A.Y., Denisova, O.V., Sapunov, V.A \& Khomutov, S.Y. 2006. Measurement quality estimation of proton-precession magnetometers. Earth, planets and space, 58, 707-710.

5. Evgeni Burovski, Patrick Callier, Yu Feng, Ralf Gommers, Ilhan Polat, Eric Quintero, Scott Sievert, Pauli Virtanen, Warren Weckesser. 2017. SciPy Reference Guide. Release 0.19.1. https://docs.scipy.org/doc/scipy-0.19.1/ scipy-ref-0.19.1.pdf (accessed: 10.09.2019).

6. Hrvoic, I. \& Newitt, L. R. 2011. Instruments and methodologies for measurement of the Earth's magnetic field. Geomagnetic Observations and Models. 105-126.

7. Jankowski, J. \& Sucksdorff, C. 1996. Guide for magnetic measurements and observatory practice. International Association of Geomagnetism and Aeronomy Boulder.

8. Khomutov, S.Y., Kusonsky, O.A., Rasson, J.L., Sapunov, V.A. 2004. The using of the absolute Overhauser magnetometers POS-1 in observatory practice: the results of the first 2.5 years. In XI IAGA Workshop on Geomagnetic observatory instruments, data acquisition and processing: book of abstracts, Kakioka, Japan.

9. Koloskov, A.V., Baru, N.A., Budanov, O.V., Bezrodny, V.G., Gavriluk, B.Yu. Paznukhov, A.V., Yampolski, Yu.M. 2013. Diagnostic of the global lightning activity based on the data of long-term monitoring of the Schumann resonance signals at UAS Academician Vernadsky. Ukrainian Antarctic Journal, 12, 170-176.

10. Marusenkov, A. 2014. Advanced LEMI magnetometers, compatible with the 1-second INTERMAGNET standard, deployed at CONRAD observatory. COBS Journal, 3, 13.

11. Marusenkov, A. 2014. Experience of 1-second magnetometer LEMI-025 use in the INTERMAGNET observatories. EGU General Assembly Conference Abstracts, 16: 5508.

12. Melnyk, G.V., Bakhmutov, V.G. 2008. The «Academic Vernadskiy» station in the network of the Ukrainian magnetic observatories of INTERMAGNET. Ukrainian Antarctic Journal, 6-7, 66-73. http://dspace.nbuv.gov.ua/ handle/ 123456789/128519 (accessed: 10.09.2019).

13. Nahayo, E. Kotzé, P. B. Cilliers, P. J. and Lotz, S. 2019. Observations from SANSA's geomagnetic network during the Saint Patrick's Day storm of 17-18 March 2015. South African Journal of Science, 115, $1 / 2$, Jan. 
14. Pos-1 processor overhauser sensor - magnetometer. 2004. User Manual, Ural State Technical University. 21.

15. Rasson, J. L., Bracke, S., Gonsette, A. and Humbled, F. 2014. PEA: new magnetic observatory in East Antarctica near Utsteinen. Fifth Symposium on Polar Science, Tachikawa, Japan, At National Institute of Polar Research. doi: 10.13140/2.1.1388.9602.

16. Sapunov, V., Denisov, A., Denisova, O. 2001. Proton and Overhauser magnetometers metrology. Contributions to Geophysics \& Geodesy, 31, 1, 119-124.

17. St-Louis, Benoit. 2012 INTERMAGNET technical reference manual. Version. 4.6. Edinburgh: INTERMAGNET office.

18. Swan, A., Shanahan, T., Turbitt, C., and Rasson, J. 2016. Hardware Developments to Determine the Transfer Fun- ction of a 1-Second Fluxgate Magnetometer. JIGU, 2, 24-29.

19. Turbitt, C., Matzka, J., Rasson, J., St-Louis, B., and Stewart, D. 2013. An instrument performance and data quality standard for intermagnet one-second data exchange. In: Proceedings of the XVth IAGA Workshop on Geomagnetic Observatory Instruments and Data Processing, Cadiz, Spain, 4-14 June 2012. 186-188. http://nora.nerc.ac. uk/507228/1/Turbitt_etal_IAGAworkshop_OneSecond DataExchange_2013.pdf. https://core.ac.uk/download/ pdf/20319990.pdf (accessed: 10.09.2019).

20. Worthington, E. W. \& Matzka, J. 2017. U.S. Geological Survey experience with the residual absolutes method. Geoscientific Instrumentation, Methods and Data Systems, 6, 419-427.

\section{А. Марусенков ${ }^{1}$, М. Леонов ${ }^{2,}$ *, В. Корепанов ${ }^{1}$, С. Леонов ${ }^{1}$, О. Колосков ${ }^{2,3}$, С. Накалов ${ }^{4}$, Ю. Отруба ${ }^{2}$}

1 Львівський Центр Інституту космічних досліджень, Національна академія наук України та Державне космічне агентство України, вул. Наукова, 5 А, м. Львів, 79060, Україна

2 Державна установа Національний антарктичний науковий центр МОН України, бульв. Тараса Шевченка, 16, м. Київ, 01601, Україна

3 Радіоастрономічний інститут, Національна академія наук України, вул. Мистецтв, 4, м. Харків, 61002, Україна

${ }^{4}$ Карпатське відділення Інституту геофізики ім. C.I. Субботіна, Національна академія наук України, вул. Наукова, 3 Б, м. Львів, 79060, Україна

* Автор для кореспонденції: g60s1981@gmail.com ОНОВЛЕННЯ INTЕRМАGNЕТ-ОБСЕРВАТОРІЇ «АРГЕНТИНСЬКІ ОСТРОВИ»
НА АНТАРКТИЧНІЙ СТАНЦІЇ «АКАДЕМІК ВЕРНАДСЬКИЙ», АНТАРКТИКА

РЕФЕРАТ. У статті описані основні особливості модернізації магнітометричного комплексу на базі варіометра LEMI025 у січні-квітні 2019 року в геомагнітній обсерваторії (код АІА) Української антарктичної станції «Академік Вернадський». Старий магнітометричний комплекс обсерваторії складався з двох варіометрів LEMI-008 (№ 02 та № 16) i скалярного магнітометра POS-1. Вимірювання LEMI-008 і POS-1 не були синхронізовані взаємно, і це було однією 3 головних проблем. Кожен вимірювальний прилад як складова всього магнітометричного комплексу мав належні індивідуальні характеристики, однак система в цілому працювала недосконало, головним чином, через відсутність взаємної синхронізації вимірювань. Також представлені деякі попередні результати тестової роботи. Мета. Одним з головних завдань модернізації обсерваторії АІА було встановлення нового варіометра, сумісного з вимогами 1-секундного стандарту даних INTERMAGNET. За два десятиліття роботи старі варіометри LEMI-008 на антарктичній станції «Академік Вернадський» показали високу стабільність базисної лінії, яка задовольняє вимоги INTERMAGNET. Але, на жаль, шумові характеристики старих варіометрів, точність синхронізації з UTC (Coordinated Universal Time, Bcecвітній координований час) та роздільна здатність, більше не відповідають сучасним вимогам INTERMAGNET для пристроїв, що видають 1-секундні дані. Вимірювання варіометрів LEMI-008 та скалярного магнітометра POS-1 не були взаємно синхронізованими. Через відсутність надійної взаємної синхронізації, різниці між модулями вектора поля, обчислені опосередковано за даними вимірювань варіометра та вимірювані безпосередньо скалярним магнітометром, варіювалися та могли бути ненадійними. При сильних геомагнітних збуреннях це погіршувало загальну точність магнітометричного комплексу як єдиної вимірювальної системи, хоча кожен окремий прилад комплексу складався з високоточних приладів. Лише один з варіометрів LEMI-008 був обладнаний синхронізацією GPS. Це ускладнювало обробку даних. Тому створення системи взаємної синхронізації вимірювань варіометра LEMI-025 та скалярного магнітометра POS-1 з точністю приблизно 0.1 с (але не гірше, ніж 1 с) за допомогою комп’ютера управління було однією 3 найважливіших задач у модернізації. Методи. Проблема взаємної синхронізації вимірювань варіометра LEMI-025 та скалярного магнітометра POS-1 (на етапі модернізації магнітометричного комплексу як усієї системи) була вирішена за 
допомогою керуючого комп’ютера шляхом періодичної корекції годинника POS-1 та запуску його циклів вимірювання із заданим випередженням. Масиви нових даних були отримані під час роботи магнітометра LEMI-025 в тестовому режимі. Використовуючи метод Бартлета та усереднення спектральних гармонік зроблено оцінки рівня власних шумів магнітометрів протягом геомагнітно спокійної доби. Опрацьовано результати абсолютних вимірювань компонент геомагнітного поля, що регулярно проводять у обсерваторії за двома методиками, та знайдено значення базисних ліній магнітометра LEMI-025. Проведено порівняльний аналіз записів модуля індукції магнітного поля Землі, що отримано за допомогою прямих вимірювань скалярним магнітометром POS-1 та розрахунком за даними варіометра LEMI-025. Аналіз дисперсії значень базисних ліній та різницевого сигналу модуля індукції магнітного поля підтвердив високу точність калібрування нового варіометру та дозволив оцінити точність орієнтації осей чутливості сенсора у географічній системі координат. Висновки. Попередні результати підтверджують, що характеристики нового варіометра LEMI-025 відповідають вимогам INTERMAGNET. Похибка орієнтації датчика магнітометра LEMI-025 не перевищує 5 дугових хвилин. Базисна лінія досить стабільна. Усі ії компоненти мають дисперсію в межах \pm 2 нТ. Їх вираженого зміщення з часом не спостерігається. Результати тестової роботи варіометра показали, що характеристики всіх магнітометричних приладів вимірювального павільйону обсерваторії АІА повинні бути взаємно узгоджені з точки зору електромагнітної сумісності.

Ключові слова: 1-секундний IНТЕРМАГНЕТ магнітометр, варіометр LEMI-025, методика синхронних вимірювань, шуми варіометра LEMI-025. 